\title{
Glycerol Transfer in Cigarette Mainstream Smoke*
}

\author{
by \\ Chuan Liu \\ British American Tobacco, R\&D Centre, Regents Park Road, Millbrook, Southampton SO15 8TL, United Kingdom
}

\begin{abstract}
SUMMARY
Experiments have been conducted to examine the effect of different levels of blend glycerol (0 to $11.4 \mathrm{wt} \%$ ) on cigarette mainstream smoke (MSS) yields. The glycerol transfer is generally found to be proportional to the blend glycerol level with the maximum glycerol contribution to the nicotine-free-dry-particulate-matter (NFDPM or "tar") per cigarette at $36 \%$ for a $11.4 \%$ blend glycerol. For cigarettes with different designs the glycerol in NFDPM may also depend on the glycerol loading per unit rod length. The tobacco rod filtration did not change significantly within the glycerol range investigated and hence plays a relatively minor role. Significant glycerol condensation ahead of the burning coal after a puff was measured. This condensation may have implications on glycerol levels in the sidestream smoke during inter-puff smouldering. [Beitr. Tabakforsch. Int. 21 (2004) 111-116]
\end{abstract}

\section{ZUSAMMENFASSUNG}

Die Auswirkung verschiedener Glycerinkonzentrationen (0 bis $14 \%$ des Gewichts) im Tabakgemisch auf die Zusammensetzung des Hauptstromrauchs (MSS) wurde untersucht. Die Übergangsmenge des Glycerins steht im allgemeinen in einem proportionalen Zusammenhang zur Menge des Glycerins im Tabakgemisch, wobei der höchste Glycerinanteil am nikotinfreien Trockenkondensat (NFDPM oder Kondensat) bei Zigaretten mit einem $1,4 \%$ igen Glycerinanteil $36 \%$ beträgt. Je nach Design der Zigaretten kann der Glyceringehalt im NFDPM auch von der absorbierten Glyzerinmenge pro Tabakstrangeinheit abhängig sein. Die Filtration durch den Tabakstrang wies bei den untersuchten Glycerinmengen keine signifikanten Unterschiede auf und spielt demnach eine relativ geringe Rolle. Eine signifikante Kondensation des Glycerins wurde nach einem Zug vor der Glutzone gemessen. Diese Kondensationsreaktion hat während der Glimmphase zwischen den Zügen möglicherweise Auswirkungen auf den Glycerinanteil des Nebenstromrauchs. [Beitr. Tabakforsch. Int. 21 (2004) 111-116]

\section{RESUME}

Les effets de teneurs en glycérol ( 0 à $11.4 \%$ du poids) dans le mélange du tabac sur le rendement dans le courant principal (CP) de la fumée ont été examinés. En général, le transfert du glycérol est en relation proportionnelle avec la teneur en glycérol dans le mélange, avec un rendement maximal en matière particulaire anhydre et exempte de nicotine (MPAEN ou goudron) par cigarette de $36 \%$ pour une teneur en glycérol de $11.4 \%$. Selon la conception des cigarettes, la teneur en glycérol dans la MPAEN peut également varier en fonction de la charge en glycérol par unité de longueur du boudin. La filtration du boudin de tabac n'a pas changé de façon significative pour les teneurs en glycérol examinées et joue donc un rôle mineur. Une condensation significative en avant du cône de combustion de la cigarette après la bouffée a été mesurée. Cette condensation peut avoir une influence sur la teneur en glycérol dans le courant secondaire de la fumée au cours de la combustion libre entre les bouffées. [Beitr. Tabakforsch. 21 (2004) 111-116]

\section{INTRODUCTION}

Glycerol (1,2,3 trihydroxypropane) is a naturally occurring ingredient of tobacco. Around 1 to $3 \%$ glycerol is also routinely used as a humectant to aid tobacco processing and to improve the smoke taste of the cigarettes (1). The percentage of glycerol in FTC "tar" among 12 commercial brand cigarettes in 1979 ranged from 8.1 to $16.9 \%$ at 1.7 to $2.2 \%$ blend glycerol (1). In addition, glycerol (mp $18^{\circ} \mathrm{C}$, bp $290{ }^{\circ} \mathrm{C}$ ) is often used as a model compound to study the transfer of semi-volatile and non-volatile substances into the mainstream smoke (MSS) particulate phase. In this respect, an earlier smoke study using ${ }^{14} \mathrm{C}$-labelled glycerol found that glycerol is readily distilled from the pyrolysis zone (2). This finding was later challenged by a separate study, again using labelled glycerol, which found no evidence for either the build-up of glycerol in the cigarette butt or elution of glycerol from the tobacco rod during smoking $(3,4)$. The authors of this work, however, noted that their 
Table 1. The first series of cigarettes and their mainstream smoke yields under the smoking regime of $35 \mathrm{~cm}^{3} / 2 \mathrm{~s} / 60 \mathrm{~s}$

\begin{tabular}{l|c|c|c|c}
\hline Parameters & A1 & B1 & C1 & D1 \\
\hline Glycerol designed (wt\%) & 0 & 3.5 & 6.0 & 12.0 \\
Glycerol measured (wt\%) & 0 & 4.2 & 6.4 & 11.4 \\
Cigarette weight (g) & 0.992 & 0.995 & 1.003 & 1.000 \\
Rod density (g cm ${ }^{-3}$ ) & 0.266 & 0.264 & 0.263 & 0.264 \\
Tobacco weight (g) & 0.724 & 0.728 & 0.735 & 0.732 \\
Cigarette length (mm) & 83 & 83 & 83 & 83 \\
Tipping length (mm) & 32 & 32 & 32 & 32 \\
CA Filter length (mm) & 27 & 27 & 27 & 27 \\
Circumference (mm) & 24.7 & 24.8 & 24.9 & 24.9 \\
Pressure drop (mmWG) & 155 & 150 & 149 & 150 \\
Paper permeability (CU) & 31 & 30 & 30 & 30 \\
Paper citrate (wt\%) & 0.59 & 0.60 & 0.72 & 0.83 \\
Ventilation (\%) & 26 & 27 & 29 & 27 \\
TPM (mg/cig) & 9.6 & 10.6 & 11.0 & 12.5 \\
Water (mg/cig) & 0.57 & 1.04 & 1.52 & 1.92 \\
Nicotine (mg/cig) & 0.93 & 0.92 & 0.82 & 0.76 \\
NFDPM (mg/cig) & 8.02 & 8.60 & 8.62 & 9.79 \\
Glycerol (mg/cig) & 0 & 1.41 & 2.08 & 3.55 \\
Puff number (per cig) & 8.7 & 8.7 & 8.6 & 9.3 \\
Tobacco blend & 70 to 74\% flue-cured lamina, 26 to \\
& $30 \%$ reconstituted tobacco \\
\hline
\end{tabular}

Table 2. The second series of cigarettes and their mainstream smoke yields under the smoking regime of $35 \mathrm{~cm}^{3} / 2 \mathrm{~s} / 60 \mathrm{~s}$

\begin{tabular}{|c|c|c|c|c|}
\hline Parameters & $\mathrm{A} 2$ & B2 & $\mathrm{C} 2$ & D2 \\
\hline Glycerol designed (wt\%) & 0.6 & 3.0 & 5.0 & 7.0 \\
\hline Glycerol measured (wt\%) & 1.0 & 2.4 & 3.3 & 5.3 \\
\hline TPM (mg/cig) & 5.9 & 6.1 & 6.5 & 6.7 \\
\hline Water (mg/cig) & 0.56 & 0.66 & 0.71 & 0.82 \\
\hline Nicotine (mg/cig) & 0.48 & 0.49 & 0.49 & 0.47 \\
\hline NFDPM (mg/cig) & 4.9 & 4.9 & 5.3 & 5.4 \\
\hline Glycerol (mg/cig) & 0.2 & 0.5 & 0.7 & 0.9 \\
\hline Puff number (per cig) & 7.4 & 7.4 & 7.4 & 7.6 \\
\hline Cigarette specifications & \multicolumn{4}{|c|}{$\begin{array}{l}\text { Cigarette weight: } 0.883 \mathrm{~g} \text {, rod } \\
\text { density: } 0.238 \mathrm{~g} \mathrm{~cm}{ }^{-3} \text {, tobacco } \\
\text { weight: } 0.638 \mathrm{~g} \text {, cigarette length: } 83 \\
\text { mm, tipping length: } 30 \mathrm{~mm} \text {, CA filter } \\
\text { length: } 25 \mathrm{~mm} \text {, circumference: } 24.4 \\
\text { mm, pressure drop: } 105 \mathrm{mmWG} \text {, } \\
\text { paper permeability: } 50 \mathrm{CU} \text {, filter } \\
\text { ventilation: } 44 \%\end{array}$} \\
\hline Tobacco blend & \multicolumn{4}{|c|}{$\begin{array}{l}46 \% \text { flue-cured, } 4 \% \text { Oriental, } 14 \% \text { air- } \\
\text { cured, } 36 \% \text { stem and reconstituted } \\
\text { tobacco. Glycerol added on the flue- } \\
\text { cured and air-cured tobacco portions. }\end{array}$} \\
\hline
\end{tabular}

conclusions were contradictory to the fact that glycerol is delivered to the MSS "tar" in increasing amounts with puff number. The absence of glycerol distillation, if true, would also be contrary to the thermal behaviour of a material under the known temperature gradient in a cigarette coal (5). A recent pyrolysis study with a set of pyrolysis parameters closely simulating a burning cigarette confirms that more than $99 \%$ of the added glycerol is released intact (6). In addition, a comprehensive investigation on the use of additives in cigarettes concluded that no adverse biological effects from adding glycerol to cigarettes were found within the experimental range (7-10).

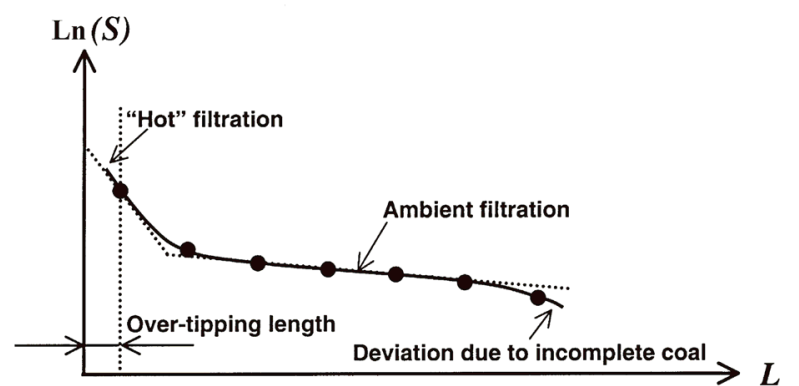

Figure 1. A schematic drawing illustrating the filtration behaviour of the cigarette rod as modelled by Eq. [1]

The focus of this work was to investigate the level and the transfer of glycerol into MSS when added at higher amounts than normally used as a humectant.

\section{EXPERIMENTAL}

\section{Cigarettes and smoking method}

Two series of cigarettes with different glycerol levels and cigarette designs were tested in this work. Details of these cigarettes are listed in Table 1 for the first (I) series and Table 2 for the second (II) series. Prior to smoking all the cigarettes were conditioned at $20{ }^{\circ} \mathrm{C} / 60 \% \mathrm{RH}$ for at least $48 \mathrm{~h}$. Tables 1 and 2 also contain the MSS yields measured under the smoking regime of $35 \mathrm{~cm}^{3} / 2 \mathrm{~s} / 60 \mathrm{~s}$.

\section{Tobacco rod filtration evaluation}

MSS yields for total particulate matter (TPM), nicotine and glycerol were also measured on a puff-by-puff basis using the approach described by BAKER and ROBINSON (11) to evaluate the tobacco rod filtration efficiency. It involved fitting the experimental smoke yields with the following equation:

$$
S=A \times e^{-\mu L}
$$

where $S$ is the yield (mg) of a particular MSS component per puff, $\mu$ is defined as the filtration coefficient of the cigarette rod $\left(\mathrm{mm}^{-1}\right), L$ is the remaining rod length $(\mathrm{mm})$ from the paper burn line (PBL), $A$ is an empirical factor. Figure 1 schematically illustrates the method. From Eq. [1], $\operatorname{Ln}(S)$ against $L$ is a straight line with a gradient of $-\mu$, thus providing a quantitative means to compare the rod filtration differences. Figure 1 also shows the measured MSS yields sometimes display an upward tail towards the $\operatorname{Ln}(S)$ axis for the last one or two puffs, a phenomenon related to socalled "hot" filtration (11). A downward deviation from the linear region, which was attributed to an incompletely formed coal (11), may also be observed for the first or the second puff.

A two-step procedure was used to obtain $L$ from Eq. [1]. First, the average rod length consumed by each puff was measured by observing the paper burn line under an infrared camera and repeated over 5 replicates. The paper burn line immediately after a 2-s puff was often not straight; so estimations had to be made. This was done by visually establishing a straight line, vertical to the cigarette rod direction, through the middle of the zigzag burn line 


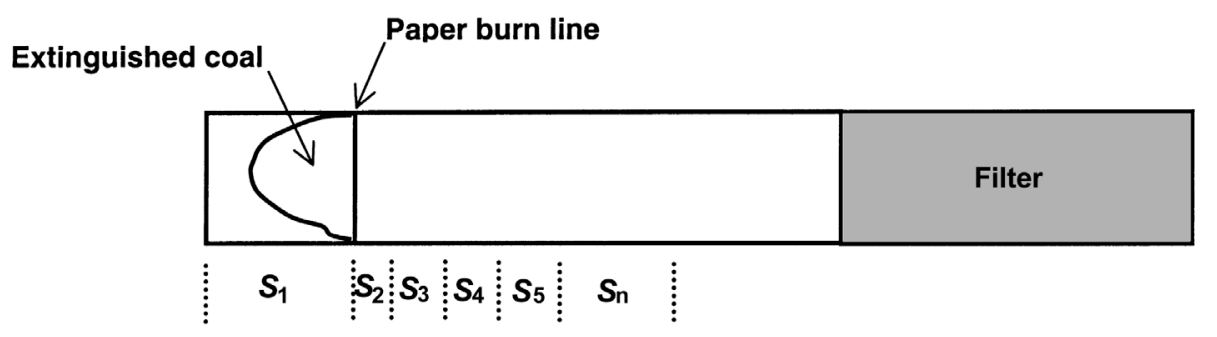

Figure 2. A schematic diagram showing the procedure used to section an extinguished cigarette to obtain the glycerol condensation profile

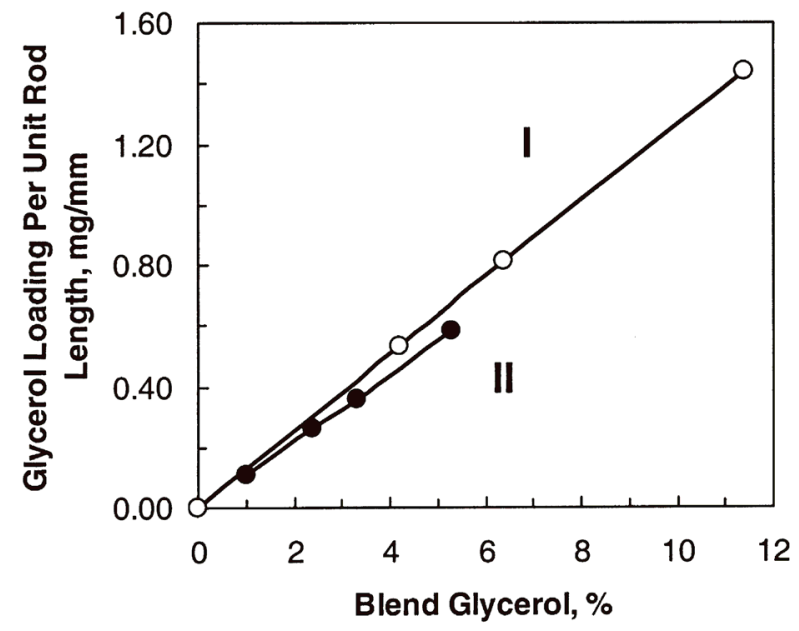

Figure 3. Glycerol loading per unit rod length as a function of the blend glycerol level

boundary and taking the position of this straight line as the paper burn line. The lighting (first) puff was not recorded and the burnt length during this puff was obtained by linear extrapolation with data from the remaining puffs. Secondly, the burnt length during the inter-puff smouldering period was estimated from the static burn rate (note that the static burn rate is generally greater than the inter-puff smouldering rate because the paper burn line immediately after a puff stays relatively static for a few seconds).

Because one of the objectives was to evaluate the tobacco rod filtration, the filter of each cigarette was removed and replaced by an impermeable cylindrical collar with identical diameter, $15 \mathrm{~mm}$ long with 5-mm overtipping. The cigarettes were smoked on a 20-port Borgwaldt smoking machine. Ten cigarettes were smoked consecutively, leaving a 10-cigarette gap to allow the Cambridge filter pad to be replaced between puffs. The smoking regime used for this particular test was $20 \mathrm{~cm}^{3} / 2 \mathrm{~s} / 60 \mathrm{~s}$. This puff volume was used to increase the puff number (hence a better defined linear region) and at the same time to keep the 10-cigarette gap in order to change the Cambridge filter pad.

\section{Glycerol profile after a puff}

To evaluate the release of glycerol during puffing, extinguished cigarettes were sectioned and analysed for the glycerol distributions along the rod by the following procedures:
- One cigarette at a time was smoked under the $35 \mathrm{~cm}^{3} / 2 \mathrm{~s} / 60 \mathrm{~s}$ regime using a single-port Borgwaldt smoking machine. After the 3rd puff (the puff numbers are listed in Tables 1 and 2), the cigarette was quickly extinguished by inserting it into a glass tube which was then sealed.

- The extinguished cigarette was carefully sectioned (with a razor blade) at designated positions shown in Figure 2.

- The paper burn line (PBL) was used as the reference (zero) position. The direction towards the unburnt rod was defined as positive (or ahead). The 1st segment $\left(S_{1}\right)$ contained all the remaining materials (the ash and part of the coal) within the negative section up to the PBL. The 2nd segment $\left(S_{2}\right)$ was a $+2 \mathrm{~mm}$ rod from the PBL, the 3rd segment $\left(S_{3}\right)$ a further $+3 \mathrm{~mm}$ section and so on. From the 5th segment $\left(S_{5}\right)$ onwards the sections were all $5 \mathrm{~mm}$ long.

Ten replicate cigarettes were smoked and sectioned. The corresponding ten segments were collected into one conical flask for glycerol analysis using a BAT method.

\section{RESULTS AND DISCUSSION}

\section{The mainstream glycerol yield}

The first series of cigarettes (A1 to D1, Table 1) had 0 to $11.4 \%$ blend glycerol. The upper limit of $11.4 \%$ is significantly higher than the conventional range at which glycerol is added as a humectant or a casing ingredient. In the second series, three out of four cigarettes (A2 to C2, Table 2) covered the lower glycerol levels. The two series of cigarettes had different rod weights: 0.720 to $0.740 \mathrm{~g}$ for the first series (Table 1) and $0.640 \mathrm{~g}$ for the second series (Table 2). This means that the glycerol loading per unit rod length $\left(\mathrm{g} \mathrm{mm}^{-1}\right)$ was higher for the heavier (first series) cigarettes at an equal blend glycerol level and the difference became greater towards higher blend glycerol levels, as shown in Figure 3. Other differences between the test cigarettes include the filter ventilation levels, the tobacco blends and the cigarette dimensions (Tables 1 and 2). All these factors contributed to the "tar" yields, which ranged from 8.0 to $9.8 \mathrm{mg}$ for the first series and from 4.9 to 5.4 for the second series cigarettes.

Figure 4 compares the MSS glycerol yield for the two series of cigarettes. It shows that the glycerol yield increases as the blend glycerol increases. For the first series of cigarettes the trend is almost linear and their glycerol 


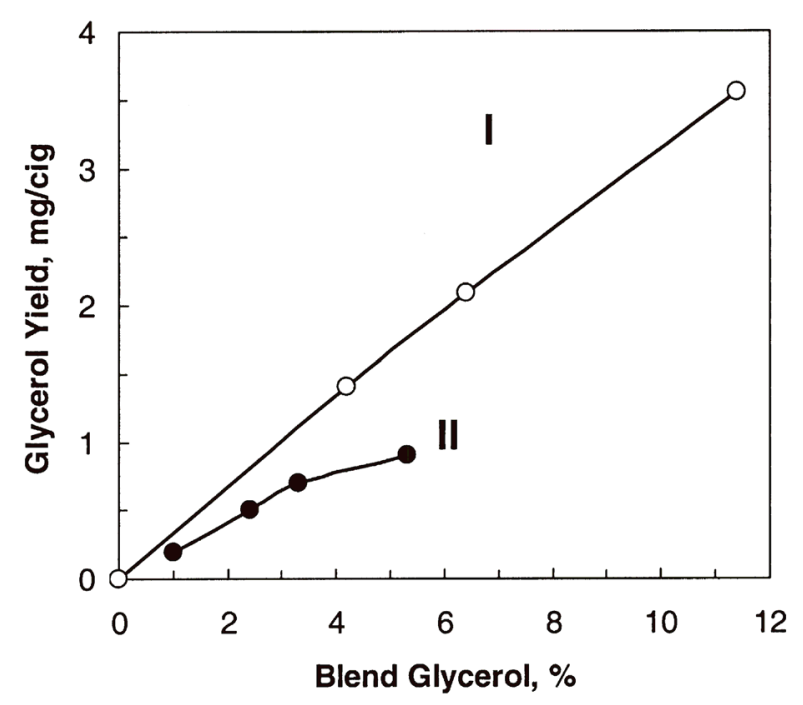

Figure 4. A plot of MSS glycerol yield vs. blend glycerol

levels are consistently higher than those from the second series. The trend for the second series of cigarette is curved, especially at $5.3 \%$ blend glycerol (the D2 cigarette).

The levels of glycerol in the NFDPM, i.e., the total "tar", and in the nicotine-humectant-free-dry-particulate-matter, i.e., the tobacco-derived "tar", are compared in Figures 5a and $5 b$, respectively. In both figures, the two ratios are almost identical and increases almost linearly at the lower blend glycerol levels, i.e., below approximately $3 \%$, which is usually the upper limit for glycerol conventionally used as a humectant (1). Evaluated by the ratio of glycerol in NFDPM, the trend shows a slight decrease for both series of cigarettes (Figure 5a). However, the trend is only discernable for the second series when evaluated by the ratio of glycerol in tobacco-derived "tar" (Figure 5b).

\section{Cigarette rod filtration efficiency}

A puff-by-puff analysis was conducted to evaluate the effect of the tobacco rod filtration on the MSS glycerol yield. The results, illustrated for the B1 (4.2\% glycerol) and D1 (11.4\% glycerol) cigarettes, are plotted in Figure 6 and fitted with Eq. [1] to extract the rod filtration coefficient.

By the parallel appearance of data plotted in Figure 6, it can be concluded that the rod filtration for the three analytes is not affected significantly by the difference in blend glycerol levels and therefore, it is not responsible for the difference in the MSS glycerol delivery efficiency. However, a different trend between the glycerol yield (Figure 6b) and the nicotine yield (Figure 6c) is apparent. This seems to suggest that the added glycerol slightly suppresses the MSS yield of nicotine from the tobacco, possibly caused by the competition for the combustion heat between the pyrolysis of tobacco and the distillation/vapourisation of glycerol. The results were also fitted with Eq. [1] to extract the filtration coefficients and they are listed in Table 3.

\section{Glycerol profile after a puff}

A blend glycerol level greater than what is thermally releasable would either be a waste or cause the cigarette
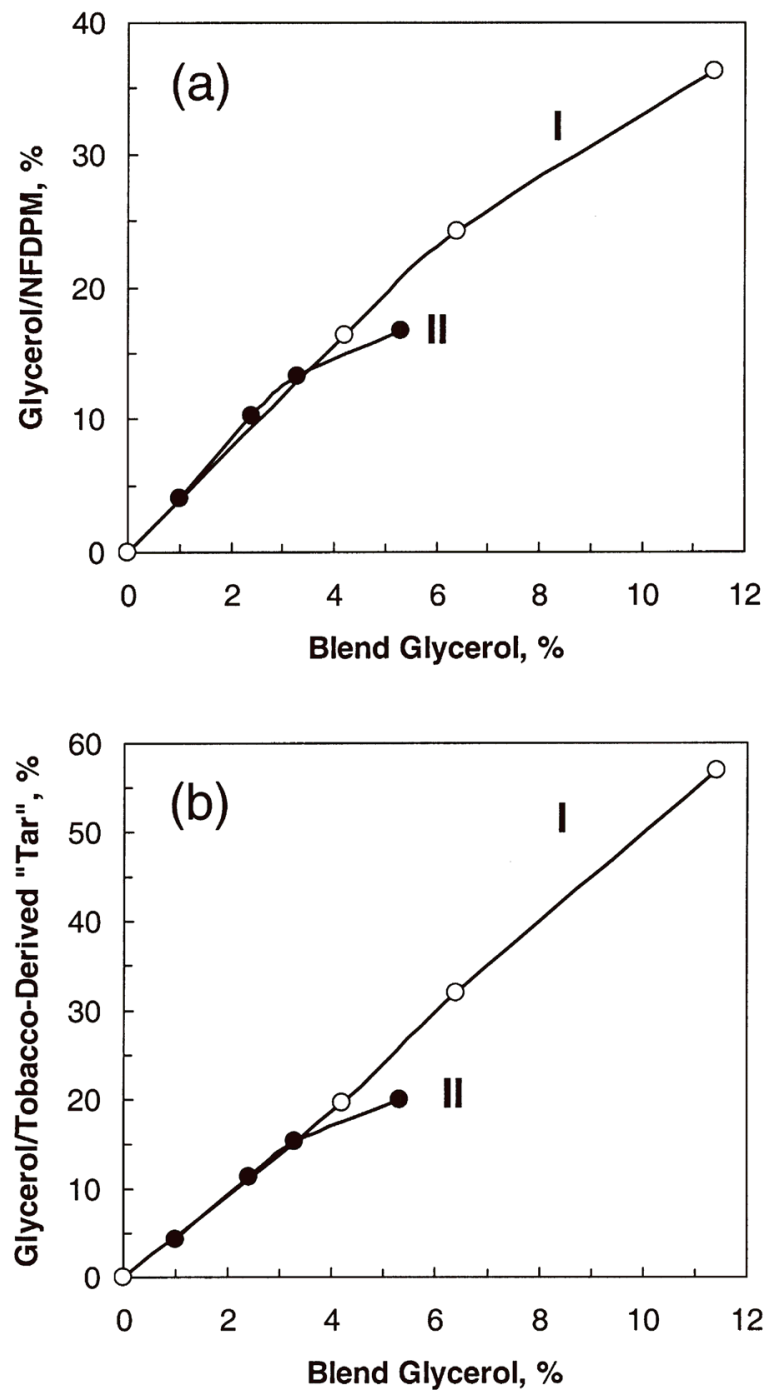

Figure 5. The percentage of glycerol in NFDPM (the total "tar") (a) and in tobacco-derived "tar" (b) as a function of blend glycerol

difficulty in smouldering. All the cigarettes tested in this work smouldered freely and separate analyses found little glycerol in the cigarette ash after smouldering. These facts suggest that the thermal energy generated during smouldering is sufficient to release all the glycerol added, even at $11.4 \%$.

It was expected that glycerol condensation ahead of the burning coal would occur, especially at higher blend glycerol levels. It was therefore decided to confirm this hypothesis by measuring the glycerol distribution along the rod after a puff for the D1 cigarette.

The measured glycerol profile immediately after the $3^{\text {rd }}$ puff from the D1 cigarette (11.4\% glycerol) is shown in Figure 7. In Figure 7 each data point in the positive direction represents the amount of glycerol found in the segment averaged over 10 replicates and plotted in the middle of the segment. A single segment was assigned for the remaining coal plus the ash attached behind the PBL (the negative section), with its glycerol content arbitrarily assigned to a 2-mm length.

For clarity, Figure 7 only shows the glycerol profile from $-2 \mathrm{~mm}$ to $+10 \mathrm{~mm}$. The remaining glycerol profile beyond 

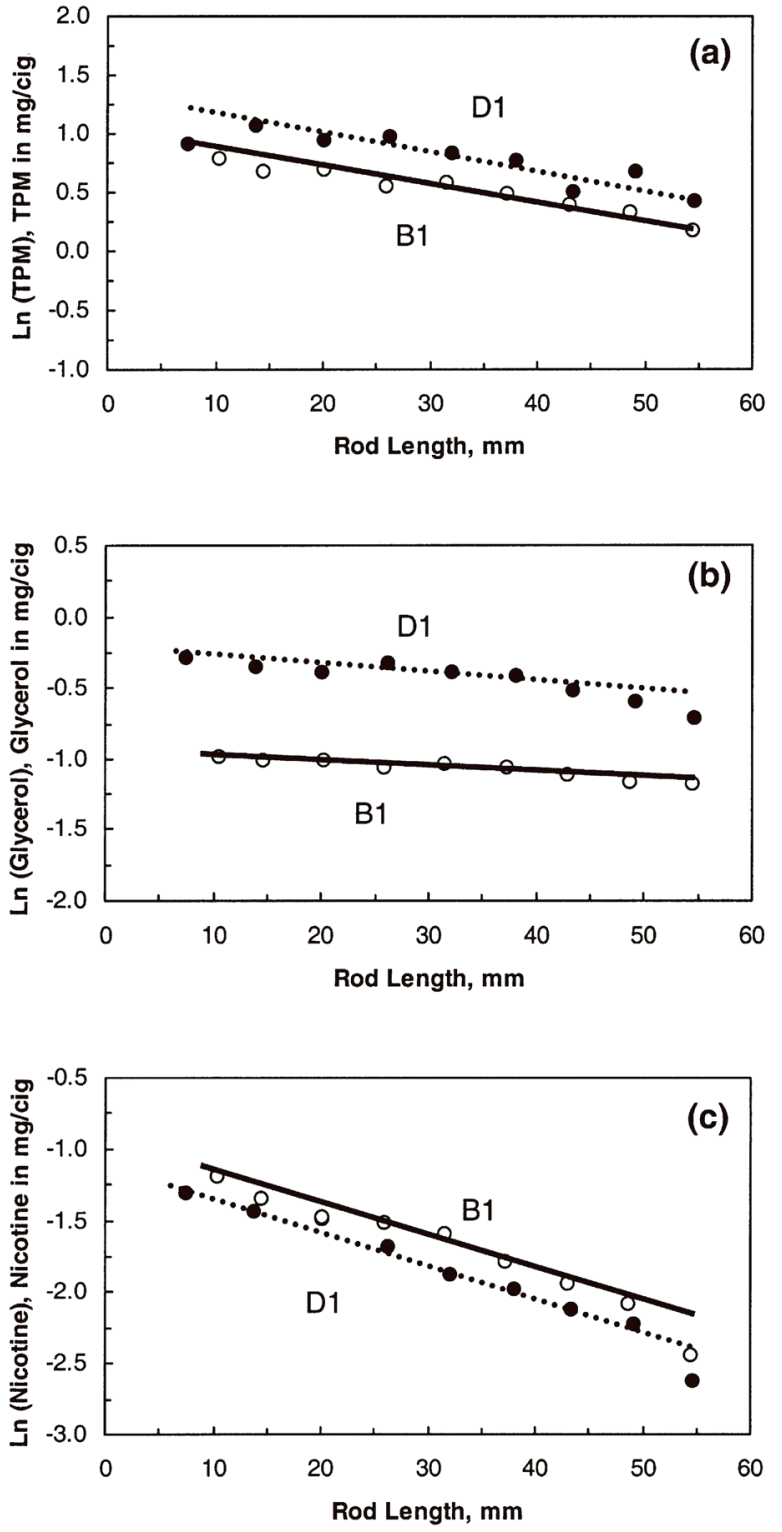

Figure 6. Smoke yields plotted to evaluate the cigarette rod filtration behaviour. B1 (4.2\% glycerol) and D1 (11.4\% glycerol) cigarettes: (a) TPM; (b) glycerol; and (c) nicotine.

$+10 \mathrm{~mm}$ is rather flat. The average glycerol loadings ( $\mathrm{mg}$ $\mathrm{mm}^{-1}$ ) from the blend analysis were $0.84 \mathrm{mg} \mathrm{mm}^{-1}$. This loading is marked in the figure by a dashed line. The peak glycerol after the $3^{\text {rd }}$ puff was found to be $1.3 \mathrm{mg} \mathrm{mm}^{-1}$ and it occurs within the first segment ahead of the PBL and falls gradually to the average level around +9 to $+10 \mathrm{~mm}$. The peak value is $55 \%$ higher than the average glycerol loading. During the subsequent inter-puff smouldering, the cigarette coal moved forward for 5 to $6 \mathrm{~mm}$ (assuming a static burn rate of 5 to $6 \mathrm{~mm} \mathrm{~min}^{-1}$ ). The amount of condensed glycerol within this 5 to $6 \mathrm{~mm}$ section is approximately $48 \%$ of the average blend glycerol.

No sidestream analytical measurements were made so it is difficult to ascertain whether or not the condensed glycerol is completely released in addition to the blend glycerol during the inter-puffing period. However, it is not totally unreasonable to assume that part of the condensed glycerol
Table 3. A list of the tobacco rod filtration coefficients obtained for two of the first series cigarettes

\begin{tabular}{l|c|c|c}
\hline \multirow{2}{*}{ Cigarette } & \multicolumn{3}{|c}{$\mu\left(\mathrm{mm}^{-1}\right)$} \\
\cline { 2 - 4 } B1 (3.5\% blend glycerol) & TPM & Nicotine & Glycerol \\
\hline D1 (11.4\% blend glycerol) & 0.0124 & 0.0073 & 0.0219 \\
\hline
\end{tabular}

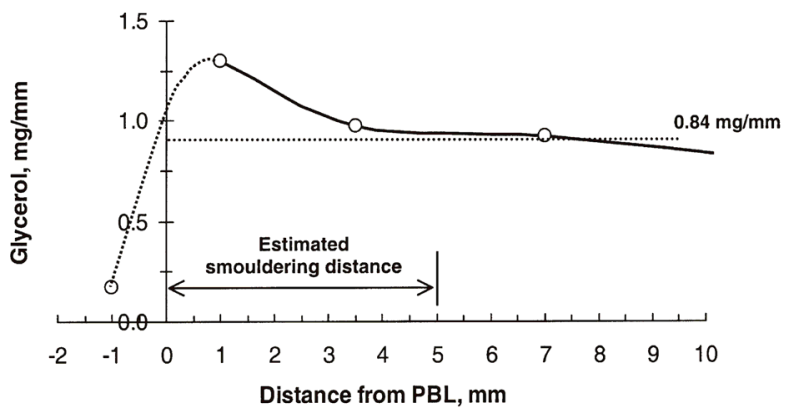

Figure 7. Tobacco rod glycerol profile from the cigarette D1 (11.4\% glycerol) immediately after a 2-s puff (the $3^{\text {rd }}$ puff). Only the region near the paper burn line (PBL) is shown.

is released into the sidestream. The extent of the glycerol condensation is a factor to consider when designing cigarettes with a higher blend glycerol level. The competition for combustion heat will be more critical during smouldering, bearing in mind that the extent of the glycerol condensation is expected to be less/greater for the earlier/later puffs than the $3^{\text {rd }}$ puff results shown in Figure 7.

\section{CONCLUSIONS}

The main conclusions of this investigation are:

- For the blend glycerol range covered in this work, the mainstream glycerol yield generally increases with the blend glycerol levels. The specific trend is dependent on the cigarette design.

- For cigarettes with otherwise identical designs, the tobacco rod filtration is not significantly altered by the different glycerol levels to influence the glycerol yield in MSS.

- Significant glycerol condensation is found ahead of the burning coal after a puff. This may have implications for the glycerol yield in sidestream smoke. Also, the maximum glycerol level allowed in the tobacco column may depend on the cigarette smoulder charactersitics. In this work the glycerol in sidestream smoke, the butt and the cigarette filter was not analysed. Future work should include a mass-balance calculation in both particulate and vapour phases to ascertain the fate of the glycerol added at high concentrations.

Acknowledgement: The author would like to thank R.R. Baker (BAT Southampton, UK), J.H. Lauterbach and F.K. St.Charles (Brown \& Williamson Tobacco, USA) for commenting the original manuscript. 


\section{REFERENCES}

1. Rodgman, A.: Some studies of the effects of additives on cigarette mainstream smoke properties. II. Casing materials and humectants; Beitr. Tabakforsch. Int. 20 (2002) 279-299.

2. Jenkins, R.W. Jr, M.K. Chavis, R.T. Bass, and T.S. Osdene: Cigarette smoke formation studies. VI. The carbon contribution to total smoke from each individual component in the 1R1-type cigarette; Beitr. Tabakforsch. Int. 10 (1980) 145-148.

3. Best, F.W.: Radiotracer studies with carbon-14 labeled glycerol: Fate in total smoke; in: Proc. International Conference on the Physical and Chemical Processes Occurring in a Burning Cigarette, edited by D.E. Townsend, R.J. Reynolds Tobacco Company, WinstonSalem NC, 1987, pp.244-260.

4. Best, F.W., T.S. Sink, and D.C. Friende: Fate of ${ }^{14}$ Cglycerol in total smoke puff by puff study; R\&DM, 1989, No. 27, January 26, see www.rirtdocs.com, $508280957-0984$.

5. Baker, R.R.: Temperature variation within a cigarette combustion coal during the smoking cycle; High Temp. Sci. 7 (1975) 236-247.

6. Baker, R.R. and L.J. Bishop: The pyrolysis of tobacco ingredients; J. Anal. Appl. Pyrol. 71 (2004) 223-311.

7. Carmines, E.L.: Evaluation of the potential effects of ingredients added to cigarettes. Part 1: Cigarette design, testing approach, and review of results; Food. Chem. Toxicol. 40 (2002) 77-91.
8. Rustemeier, K., R. Stabbert, H.J. Haussmann, E. Roemer, and E.L. Carmines: Evaluation of the potential effects of ingredients added to cigarettes. Part 2: Chemical composition of mainstream smoke; Food Chem. Toxicol. 40 (2002) 93-104.

9. Roemer, E., F.J. Tewes, T.J. Meisgen, D.J. Veltel, and E.L. Carmines: Evaluation of the potential effects of ingredients added to cigarettes. Part 3: In vitro genotoxicity and cytotoxicity; Food Chem. Toxicol. 40 (2002) 105-111.

10. Vanscheeuwijck, P.M., A. Teredesai, P.M. Terpstra, J. Verbeeck, P. Kuhl, B. Gerstenberg, S. Gebel, and E.L. Carmines: Evaluation of the potential effects of ingredients added to cigarettes. Part 4: Subchronic inhalation studies; Food Chem. Toxicol. 40 (2002) 113-131.

11. Baker, R.R. and D. P. Robinson: Tobacco combustionThe last ten years; Rec. Adv. Tob. Sci. 16 (1990) 3-71.

Address for correspondence

Chuan Liu

British American Tobacco

$R \& D$ Centre

Regents Park Road

Millbrook

Southampton SO15 8TL

United Kingdom

E-mail:chuan_liu@bat.com 